Philopatry, Site Tenacity, and Mate Fidelity in the Semipalmated Sandpiper Author(s): Cheri L. Gratto, R. I. G. Morrison, Fred Cooke

Reviewed work(s):

Source: The Auk, Vol. 102, No. 1 (Jan., 1985), pp. 16-24

Published by: University of California Press on behalf of the American Ornithologists' Union

Stable URL: http://www.jstor.org/stable/4086818

Accessed: 09/04/2012 17:07

Your use of the JSTOR archive indicates your acceptance of the Terms \& Conditions of Use, available at http://www.jstor.org/page/info/about/policies/terms.jsp

JSTOR is a not-for-profit service that helps scholars, researchers, and students discover, use, and build upon a wide range of content in a trusted digital archive. We use information technology and tools to increase productivity and facilitate new forms of scholarship. For more information about JSTOR, please contact support@jstor.org. 


\title{
PHILOPATRY, SITE TENACITY, AND MATE FIDELITY IN THE SEMIPALMATED SANDPIPER
}

\author{
Cheri L. Gratto, ${ }^{1}$ R. I. G. Morrison, ${ }^{2}$ AND Fred CoOKE ${ }^{1}$ \\ ${ }^{1}$ Department of Biology, Queen's University, Kingston, Ontario K7L 3N6 Canada, and \\ ${ }^{2}$ Canadian Wildlife Service, 1725 Woodward Drive, Ottawa, Ontario K1A 0E7 Canada
}

\begin{abstract}
Philopatry, site tenacity, and mate fidelity were examined in a 5-yr study of a population of male-territorial, monogamous Semipalmated Sandpipers (Calidris pusilla) breeding at La Pérouse Bay, near Churchill, Manitoba. There was no sex bias in natal philopatry and no significant difference in adult philopatry, although males tended to return to the breeding area at higher frequencies than females. However, males nested significantly closer to previous nests than did females. Pairs that had reunited did not move as far from their previous nest site as birds that had changed mates, and this effect was more pronounced in females. Birds that had nested successfully the previous year returned at higher rates than those that had been unsuccessful. However, there was no significant difference in distance moved from a previously successful vs. unsuccessful nest. There also was no significant difference in site tenacity when distances one and two years or two and three years apart were compared. However, nest distances increased significantly when three years had elapsed between utilization of sites.

Each year approximately $50 \%$ of the marked birds in the study area had reunited with their mate of the previous year. If both members of the pair returned, close to $80 \%$ remained paired. There was no tendency for birds that had "divorced" to have been less successful nesters in the previous year, compared to pairs that had reunited. Subsequent nesting success was not significantly different between birds that had changed or retained mates. However, in 1 of $4 \mathrm{yr}$, nests of pairs that had changed mates hatched significantly later than did those of remated pairs. Received 23 April 1984, accepted 4 October 1984.
\end{abstract}

IN recent years a number of authors have discussed the influence of social structure and mating system on philopatry and dispersal. Gauthreaux (1978) proposed that dominance hierarchies in a population could explain differential dispersal and migration between the sexes, as well as among age groups. Greenwood (1980), however, refuted Gauthreaux's hypothesis with respect to differential sex dispersal. Greenwood noted that while males are dominant to females in most mammals, mammals rarely show female-biased dispersal. He suggested that the direction of the sex bias in dispersal could be predicted from the mating system. In a resource-defense (territorial) system, the sex that defends the resource would be expected to be more philopatric. This assumes that acquisition and/or maintenance of a breeding territory, for example, would be facilitated by familiarity with the area. Dispersal of one sex relative to the other is thought to be related to the level of genetic similarity between potential mates insofar as no dispersal may present a loss in breeding success due to inbreeding, but too much dispersal may lead to genetic incompatibility (Shields 1983).

Factors other than gender also may have an effect on adult philopatry and site tenacity. These include mate change (Wilcox 1959), previous breeding success (Oring and Lank 1982, Oring et al. 1983), and number of years elapsed between nest sites.

Levels of adult philopatry may affect mate fidelity in species that do not remain together outside the breeding season. For example, in many shorebirds (Soikkeli 1967, Holmes 1971), unless both members of the pair return to the same breeding territory, the pair is unlikely to reunite in subsequent years. Levels of mate fidelity vary greatly among species, with longlived birds generally retaining the same mate for several years (Rowley 1983). Several studies of seabirds have indicated a higher productivity in pairs retaining the same mate compared to those that had changed mates (e.g. Mills 1973, Coulson and Thomas 1983). Information on the advantages of mate fidelity is primarily confined to seabirds (Rowley 1983). 
The faithfulness of a bird to its breeding area has been measured in several ways. Philopatry usually refers to the return rate of birds to a given study area, while site tenacity is the measure of actual distance, or number of territories, moved between years by returning individuals within the study area. Since these two measures are based on slightly different premises, conclusions drawn may also differ.

The Semipalmated Sandpiper (Calidris pusilla) is a small, migratory, male-territorial, monogamous shorebird. This paper presents data on factors affecting both the philopatry and site tenacity of a marked population of Semipalmated Sandpipers and examines the effect of mate fidelity on nesting success.

\section{StUdy AREA AND METHODS}

The study was carried out at the Queen's University Tundra Biology Station at La Pérouse Bay, $40 \mathrm{~km}$ east of Churchill, Manitoba, in the summers of 1980 1984. Semipalmated Sandpipers were observed in a $2-\mathrm{km}^{2}$ area in the delta of the Mast River, where nests occurred in dry, shrubby areas consisting mainly of Salix brachycarpa or Betula glandulosa and mixed sedges and grasses. The average territory size was 1.0 ha, including defended water areas. Approximately 100 pairs nested within the study area each year.

Birds were captured on nests using walk-in traps of chicken wire, with a circular $(35 \mathrm{~cm}$ in diameter and $25 \mathrm{~cm}$ high) keyhole design. The birds were marked with individual color-band combinations. The largest member of the pair, usually determined by bill length, was normally assumed to be the female (Prater et al. 1977). In many instances sexing was verified by behavior (flight displays, copulation).

Nests were marked by stakes, numbered, and mapped on $10 \times$ enlargements of aerial photographs (scale 1:2500, allowing accuracy to at least $3 \mathrm{~m}$; Abraham 1980). Nests were checked every 1-3 days. We considered a nest successful if at least one egg hatched or if eggs had been strongly pipped 1-2 days before we subsequently found an empty nest.

We have defined natal philopatry as the return of birds to the area of their birth. Adult philopatry is the return of birds to the area of a previous breeding attempt. Site tenacity is measured by actual distance from a nest to a nest of the same bird in a previous year. Actual distance (nest distance) is a more accurate measurement of site tenacity than number of territories moved, but the latter probably is more biologically meaningful (Greenwood and Harvey 1982). It was not possible to map territories for the large number of birds in the study area. For comparative purposes in the same study area, the conclusions should be very similar, particularly because nesting densi- ties and distances moved for each group tested remained virtually constant each year $(P>0.05$, MannWhitney $U$-test).

Throughout this paper nonparametric statistics (Mann-Whitney $U$-test) were used to compare sets of nest distances because the data were not distributed normally (see Fig. 1). Multidimensional contingency analysis (MDCA) was used for frequency data (Dixon and Brown 1979; see also Colgan and Smith 1978, Cooke et al. in press). This allows simultaneous analysis of the interactions between three or more variables (e.g. return rate, success, and year) instead of requiring many individual two-way contingency tables.

In calculations of interyear nest distances where data from more than one year were combined, some individuals may be represented more than once. We included all such data because measures of nest distances were independent of individual (ANOVA, $P>$ 0.05).

\section{RESUlTS}

Effect of years elapsed on adult site tenacity.Some birds first found on nests in 1980 were still breeding in 1984. Therefore nest distances $1,2,3$, and 4 years apart were obtained. Because there were only 4 birds from 1980 found breeding in 1984, these data were not included in Table 1. There were no significant differences between sets of nest sites utilized 1 and 2 yr apart, or 2 and 3 yr apart (Table 1). However, in several instances nest distances $3 \mathrm{yr}$ apart were significantly larger than those 1 yr apart. Internest distances for females showed no consistent trend. Only nest sites separated by 1 yr were used in subsequent comparisons in this paper. However, whenever a significant difference between groups (e.g. males vs. females) was found in the 1-yr apart data, the same trend was observed for at least 9 of the 10 year-pairs (1980 and 1981, 1981 and 1982, 1982 and 1983, 1983 and 1984, 1980 and 1982, 1981 and 1983, 1982 and 1984, 1980 and 1983, 1981 and 1984, 1980 and 1984), including those with nest distances 2, 3, and 4 yr apart.

In at least 13 instances (of 305 nesting attempts), Semipalmated Sandpipers reused their nestcup of the previous year. On two occasions, nestcups were known to have been used by a different pair when the original birds did not return. Nestcups also were exchanged between species: four pairs of Semipalmated Sandpipers used Red-necked Phalarope (Phalaropus lobatus) cups, and another pair used a Horned Lark (Eremophila alpestris) cup. Semipalmated Sandpip- 
TABLE 1. Comparison of nest distances (m) 1, 2, and $3 \mathrm{yr}$ apart, for breeding birds. ${ }^{\mathrm{a}}$

\begin{tabular}{|c|c|c|c|c|c|c|c|c|c|c|c|c|}
\hline & \multicolumn{12}{|c|}{ Number of years apart } \\
\hline & \multicolumn{3}{|c|}{1} & \multirow[b]{2}{*}{$P^{b}$} & \multicolumn{3}{|c|}{2} & \multirow[b]{2}{*}{$P^{c}$} & \multicolumn{3}{|c|}{3} & \multirow[b]{2}{*}{$P^{\mathrm{d}}$} \\
\hline & $n$ & Median & Range & & $n$ & Median & Range & & $n$ & Median & Range & \\
\hline Alle & 174 & 53 & $0-848$ & NS & 72 & 63 & $6-855$ & NS & 25 & 80 & $21-816$ & * \\
\hline $\begin{array}{l}\text { Reunited } \\
\text { pairs }\end{array}$ & 64 & 40 & $0-570$ & NS & 16 & 38 & $15-269$ & NS & 5 & 66 & $29-119$ & NS \\
\hline $\begin{array}{l}\text { Female mate } \\
\text { change }\end{array}$ & 32 & 174 & $23-825$ & NS & 21 & 138 & $6-855$ & NS & 9 & 143 & $36-816$ & NS \\
\hline $\begin{array}{l}\text { Male mate } \\
\text { change }\end{array}$ & 46 & 41 & $0-534$ & NS & 29 & 63 & $8-609$ & NS & 6 & 88 & $54-178$ & $*$ \\
\hline
\end{tabular}

a Nest sites 1 yr apart are from the year-pairs 1980 and 1981, 1981 and 1982, 1982 and 1983, and 1983 and 1984; 2 yr apart, 1980 and 1982, 1981 and 1983, and 1982 and 1984; and 3 yr apart, 1980 and 1983, and 1981 and 1984. ${ }^{*} P<0.05$ (Mann-Whitney $U$-test); NS = not significant.

b Comparison between 1 and 2 yr apart.

c Comparison between 2 and 3 yr apart.

d Comparison between 1 and 3 yr apart.

e Includes nests where one mate was unknown.

er nestcups were used by a Least Sandpiper (C. minutilla) and a phalarope. In 1983 a Semipalmated Sandpiper nested in a cup that had been used by a Savannah Sparrow (Passerculus sandwichensis) in 1982 and by a phalarope in 1981 . Another nestcup was used by a phalarope in 1980, a Dunlin (C. alpina) until the eggs were destroyed and then a Semipalmated Sandpiper in 1981, and another phalarope in 1982.

Sexual differences in philopatry and site tenacity. - Five percent $(20 / 375)$ of all nestlings banded from 1980 to 1983 were found in the study area in subsequent years. Eleven males and 9 females returned, and of these 7 males and 7 females were found on nests. Thus, there was no indication of a sex bias in natal philopatry, assuming that half of the nestlings banded were males and half females ( $G$-test, $P>$ 0.05). Distance between natal and first known breeding site was measured for 10 individuals over all years. Females $(n=6$, median $=204 \mathrm{~m}$, range $=125-481 \mathrm{~m}$ ) nested significantly closer than males $(n=4$, median $=549 \mathrm{~m}$, range $=$ $406-815 \mathrm{~m})$ to their natal nest sites $(P<0.02$, Mann-Whitney $U$-test).

Adult philopatry was measured by calculating return rates in the year following identification at a nest for each sex (Table 2). There was no significant difference between the sexes, although a smaller proportion of females returned each year. The increase in return rate of Semipalmated Sandpipers from 1981 to 1983 probably is due to more complete censusing rather than differences in yearly return rates.
In a high-predation year (such as 1981), birds were easily missed if their nest was destroyed early, because many apparently did not attempt to renest. Thus, some birds seen in the area before incubation were not found at nests later. Although this variation in censusing resulted in differences in measured return rates, it should not have affected other factors, such as relative return of the sexes.

Sexual differences in adult site tenacity also were tested. When all males were included, they nested a median of $40 \mathrm{~m}(n=125$, range $=0-$ 570) from their previous nest sites, and all females a median of $60 \mathrm{~m}(n=109$, range $=0$ 847). If pairs reunite, there obviously is no difference between the sexes in site tenacity. Therefore, only instances where mates were

TABLE 2. Adult philopatry: the relative return rate of each sex based on breeding birds seen at nests in successive years. Pertinent associations for the MDCA models were those between sex and return rate $(\mathrm{df}=1)$, sex and year $(\mathrm{df}=3)$, and return rate and year $(\mathrm{df}=3)$. Data were not combined over years because there was a significant interaction between return rate and year (MDCA, $P<0.05) .^{a}$

\begin{tabular}{ccc}
\hline \hline \multirow{2}{*}{$\begin{array}{l}\text { Year of } \\
\text { return }\end{array}$} & \multicolumn{2}{c}{ Percent found at nest } \\
\cline { 2 - 3 } & Female & \multicolumn{1}{c}{ Male } \\
\hline 1981 & $33(14 / 42)$ & $37(16 / 43)$ \\
1982 & $45(24 / 53)$ & $51(27 / 53)$ \\
1983 & $57(39 / 69)$ & $57(40 / 70)$ \\
1984 & $39(36 / 92)$ & $44(44 / 100)$ \\
\hline
\end{tabular}

a There was no significant difference between the sexes in return rate (MDCA, $P=0.39$ ). 


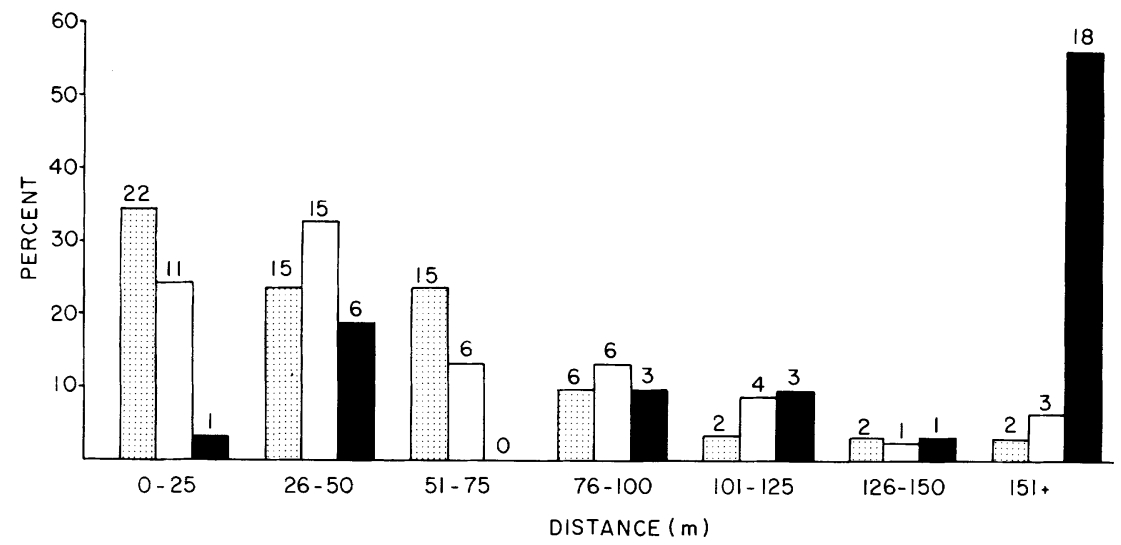

Fig. 1. Percent frequencies of interyear nest distances (1 yr apart) for same-mate pairs, mate-change males, and mate-change females. Numbers above bars are sample sizes; shaded bars are same-mate pairs ( $n=64)$, white bars are males that changed mates $(n=46)$, and black bars are females that changed mates $(n=32)$.

known to have changed were used in Table 3 and Fig. 1. Males nested significantly closer to previous nests than did females.

Effect of mate change and nesting success on philopatry and site tenacity.-Distance moved was compared for birds with the same mate and those known to have changed mates (Table 3 and Fig. 1). Same-mate females nested closer to previous nests than did females that had changed mates, while the difference was either barely or not significant with respect to males.

Birds that had nested unsuccessfully returned the following year at a lower frequency than birds that had been successful (Table 4). Site tenacity also was compared for birds that had nested successfully the previous year and those that had not (Table 5). There was no significant difference in distance between nests with pairs retaining the same mate, with males that changed mates, or with females that changed mates. There were also no consistent trends in all year-pairs.

Effect of previous nesting success on mate fidelity.-Approximately $50 \%$ of the marked birds in the study area had different mates from the previous year, usually because one member of the pair did not return to the study area (Table 6). Presumably, most of the birds that did not return had died, but there were instances where both mates returned but did not re-pair. Overall, of pairs where both adults were found at the study area in the following year, $81 \%(64 /$ $79)$ had reunited and $19 \%(15 / 79)$ had divorced (i.e. both returned but did not reunite).

Only instances where both members of the pair returned to the study area were used to examine the effect of previous nesting success on mate fidelity, because if only one mate survived, the pair obviously could not reunite. Of the 15 instances where both members of a pair

TABLE 3. The effect of sex and mate change on site tenacity. Data from 1982 and 1984 were significantly different $(P>0.05$, Mann-Whitney $U$-test $)$ and therefore were not combined. ${ }^{a}$

\begin{tabular}{|c|c|c|c|c|c|c|c|c|c|c|c|c|}
\hline & \multicolumn{11}{|c|}{ Distance between nests (m) } & \multirow[b]{3}{*}{$P^{\mathrm{d}}$} \\
\hline & \multicolumn{3}{|c|}{ Female mate change } & \multirow[b]{2}{*}{$P^{\mathrm{b}}$} & \multicolumn{3}{|c|}{ Same-mate pairs } & \multirow[b]{2}{*}{$P^{c}$} & \multicolumn{3}{|c|}{ Male mate change } & \\
\hline & $n$ & Median & Range & & $n$ & Median & Range & & $n$ & Median & Range & \\
\hline 1981 and 1982 & 8 & 99 & $43-235$ & $* *$ & 34 & 51 & $0-335$ & $*$ & 18 & 58 & $10-120$ & $*$ \\
\hline 1983 and 1984 & 24 & 232 & $23-803$ & $* * *$ & 45 & 43 & $0-570$ & NS & 28 & 37 & $0-534$ & $* * *$ \\
\hline
\end{tabular}

a * $P<0.05,{ }^{* *} P<0.01,{ }^{* *} P<0.001, \mathrm{NS}=$ not significant (Mann-Whitney $U$-tests).

${ }^{b}$ Comparison between mate-change females and same-mate pairs.

' Comparison between same-mate pairs and mate-change males.

d Comparison between mate-change females and males. 
TABLE 4. The effect of previous nesting success on return rate. Pertinent associations for the MDCA models were those between previous nesting success and return rate $(\mathrm{df}=1)$, nesting success and year $(\mathrm{df}=3)$, and return rate and year $(\mathrm{df}=3)$. Data were not combined over years because there were significant interactions between return rate and year and between success and year (MDCA, $P<0.05)^{a}$

\begin{tabular}{cccl}
\hline \hline & & \multicolumn{2}{c}{ Percent returning } \\
\cline { 3 - 4 } Sex & Years & $\begin{array}{c}\% \\
\text { Successful }\end{array}$ & $\begin{array}{c}\text { \% Unsuc- } \\
\text { cessful }\end{array}$ \\
\hline Females & 1980 and 1981 & $37(11 / 30)$ & $25(3 / 12)$ \\
& 1981 and 1982 & $56(10 / 18)$ & $31(10 / 32)$ \\
& 1982 and 1983 & $65(32 / 49)$ & $35(7 / 20)$ \\
Males & 1983 and 1984 & $62(24 / 39)$ & $20(10 / 51)$ \\
& 1980 and 1981 & $47(14 / 30)$ & $15(2 / 13)$ \\
& 1981 and 1982 & $68(13 / 19)$ & $48(14 / 29)$ \\
& 1982 and 1983 & $68(34 / 50)$ & $35(7 / 20)$ \\
& 1983 and 1984 & $71(30 / 42)$ & $24(14 / 58)$ \\
\hline
\end{tabular}

a There were significant differences in return rate between previously successful and unsuccessful females (MDCA, $P<0.001$ ) and between previously successful and unsuccessful males (MDCA, $P<0.001$ ).

were known to be present the following year but had changed mates, previous nesting success was not significantly different between same-mate and divorced pairs (Table 7).

Effect of mate change on nesting success and hatch date.-The effect of mate change on nesting success was measured for each year (Table 8 ). There was no significant difference in nesting success in the following year between birds that had changed mates and those that had not. In 1982, nests of birds that had changed mates hatched significantly later than those of samemate pairs (Table 9). There was no significant difference between the two mate type groups in any of the other three years.
TABLE 6. Mate fidelity of birds found in the study area the following year.

\begin{tabular}{ccc}
\hline \hline & \multicolumn{2}{c}{ Birds that retained mates (\%) } \\
\cline { 2 - 3 } Years & $\begin{array}{c}\text { All marked } \\
\text { birds }^{\mathrm{a}}\end{array}$ & $\begin{array}{c}\text { Both returned } \\
\text { only }^{\mathrm{b}}\end{array}$ \\
\hline 1980 and 1981 & $47(7 / 15)$ & $70(7 / 10)$ \\
1981 and 1982 & $48(12 / 25)$ & $75(12 / 16)$ \\
1982 and 1983 & $57(27 / 47)$ & $90(27 / 30)$ \\
1983 and 1984 & $40(18 / 45)$ & $78(18 / 23)$ \\
\hline
\end{tabular}

a Percentage of marked birds in the study area known to have retained the same mate as the previous year. Mate change resulted from mortality or nonreturn of one member of the pair, or from divorce (both returned but did not reunite).

b Percentage of mate fidelity in all instances where both members of the pair returned to the study area and, therefore, mate change was only by divorce.

\section{DISCUSSION}

Because the Semipalmated Sandpiper has a male-territorial breeding system, Greenwood's (1980) predictions indicate that philopatry should be male-biased. The data on natal philopatry in this study did not indicate a sex bias in dispersal. Oring and Lank $(1982,1984)$ compiled results from several studies of small, monogamous shorebirds and concluded that natal philopatry appeared equal between the sexes. Redmond and Jenni (1982) found that Longbilled Curlews (Numenius americanus) show a strong male bias in natal philopatry and suggested that this may be more common in larger, long-lived shorebirds. They reasoned that as longevity increases, the potential for inbreeding becomes stronger. The optimal level of inbreeding (where benefits accrued balance the cost of inbreeding depression), as suggested by Shields (1983), therefore may be obtained

TABLE 5. The effect of previous nesting success on site tenacity. Data from 1981 and 1983 , and 1981 and 1984, were significantly different $(P>0.05$, Mann-Whitney $U$-test $)$ and therefore were not combined.

\begin{tabular}{|c|c|c|c|c|c|c|c|c|}
\hline & \multirow[b]{3}{*}{ Years } & \multicolumn{7}{|c|}{ Distance between nests (m) } \\
\hline & & \multicolumn{3}{|c|}{ Successful } & \multirow[b]{2}{*}{$P$} & \multicolumn{3}{|c|}{ Unsuccessful } \\
\hline & & $n$ & Median & Range & & $n$ & Median & Range \\
\hline Same-mate pairs & $\begin{array}{l}1981 \text { and } 1982 \\
1983 \text { and } 1984\end{array}$ & $\begin{array}{l}13 \\
39\end{array}$ & $\begin{array}{l}18 \\
49\end{array}$ & $\begin{array}{l}0-65 \\
0-570\end{array}$ & $\begin{array}{l}\mathrm{NS}^{\mathrm{a}} \\
\mathrm{NS}\end{array}$ & $\begin{array}{l}5 \\
6\end{array}$ & $\begin{array}{l}33 \\
33\end{array}$ & $\begin{array}{c}26-125 \\
6-83\end{array}$ \\
\hline Female mate change & $\begin{array}{l}1981 \text { and } 1982 \\
1983 \text { and } 1984\end{array}$ & $\begin{array}{r}5 \\
13\end{array}$ & $\begin{array}{l}124 \\
231\end{array}$ & $\begin{array}{l}50-235 \\
31-771\end{array}$ & $\begin{array}{l}\text { NS } \\
\text { NS }\end{array}$ & $\begin{array}{r}3 \\
11\end{array}$ & $\begin{array}{r}82 \\
234\end{array}$ & $\begin{array}{l}43-118 \\
23-825\end{array}$ \\
\hline Male mate change & $\begin{array}{l}1981 \text { and } 1982 \\
1983 \text { and } 1984\end{array}$ & $\begin{array}{l}11 \\
19\end{array}$ & $\begin{array}{l}58 \\
34\end{array}$ & $\begin{array}{r}28-120 \\
0-111\end{array}$ & $\begin{array}{l}\text { NS } \\
\text { NS }\end{array}$ & $\begin{array}{l}7 \\
9\end{array}$ & $\begin{array}{r}69 \\
104\end{array}$ & $\begin{array}{l}10-86 \\
6-534\end{array}$ \\
\hline
\end{tabular}

a $\mathrm{NS}=$ not significant (Mann-Whitney $U$-test). 
TABLE 7. The effect of previous nesting success on mate fidelity in the following year. Pertinent associations for the MDCA models were those between mate change and previous nesting success $(\mathrm{df}=1)$, mate change and year $(\mathrm{df}=3)$, and previous success and year $(\mathrm{df}=3)$. Data were combined over years because there were no significant interactions between either nesting success and year or mate change and year (MDCA, $P>0.05)$.

\begin{tabular}{ccc}
\hline \hline & \multicolumn{2}{c}{ Percent divorce $^{\mathrm{b}}$} \\
\cline { 2 - 3 } $\begin{array}{c}\text { Following } \\
\text { year }\end{array}$ & $\begin{array}{c}\text { Successful } \\
\text { nesters in } \\
\text { previous year }\end{array}$ & $\begin{array}{c}\text { Unsuccessful } \\
\text { nesters in } \\
\text { previous year }\end{array}$ \\
\hline 1981 & $18(2 / 11)$ & $25(1 / 4)$ \\
1982 & $14(2 / 14)$ & $20(2 / 10)$ \\
1983 & $5(2 / 38)$ & $11(1 / 9)$ \\
1984 & $14(4 / 29)$ & $6(1 / 16)$ \\
All & $11(10 / 92)$ & $13(5 / 39)$ \\
\hline
\end{tabular}

a There was no significant difference in subsequent divorce rates between previously successful and unsuccessful nesters (MDCA, $P=0.91$ ).

b Divorce refers to instances where both members of the pair were present but not reunited.

by a sex bias in philopatry. According to Redmond and Jenni (1982), then, because there is less potential for inbreeding in smaller, shorter-lived shorebirds, selection for sex-biased philopatry would be weakened. Indeed, in the present study natal nest-site tenacity was significantly higher for females than for males. While the low sample size (6 vs. 4 ) may preclude conclusion of a male-biased dispersal, which would be opposite to that predicted by Greenwood, males certainly did not nest closer than females to natal nest sites. If females are

TABLE 8. The effect of mate change on nesting success. Pertinent associations for the MDCA models were those between mate change and nesting success $(d f=1)$, mate change and year $(d f=3)$, and nesting success and year $(\mathrm{df}=3)$. Data were not combined over years because there was a significant interaction between nesting success and year (MDCA, $P<0.05)$. $^{\text {a }}$

\begin{tabular}{ccc}
\hline \hline & \multicolumn{2}{c}{ Percent successful } \\
\cline { 2 - 3 } Year & Same mate & Different mate \\
\hline 1981 & $43(3 / 7)$ & $38(3 / 8)$ \\
1982 & $67(8 / 12)$ & $87(13 / 15)$ \\
1983 & $33(5 / 15)$ & $22(6 / 27)$ \\
1984 & $67(12 / 18)$ & $73(16 / 22)$ \\
\hline
\end{tabular}

a There was no significant difference in subsequent nesting success between birds retaining or changing mates (MDCA, $P=0.78$ ).
TABLE 9. The effect of mate change on hatch date.

\begin{tabular}{crrrrrrr}
\hline & \multicolumn{2}{c}{ Same mate } & & \multicolumn{2}{c}{ Different mate } \\
\cline { 2 - 3 } \cline { 6 - 7 } Year & $n$ & $\begin{array}{c}\text { Mean date } \\
\text { (SE) }\end{array}$ & & $P$ & $n$ & $\begin{array}{c}\text { Mean date } \\
\text { (SE) }\end{array}$ \\
\hline 1981 & 3 & $10(0.7)$ & NS & 3 & $9(0.9)$ \\
1982 & 8 & $15(0.5)$ & $*$ & 14 & $17(0.9)$ \\
1983 & 6 & $11(0.5)$ & NS & 5 & $14(3.1)$ \\
1984 & 12 & $7(1.0)$ & NS & 16 & $8(1.6)$ \\
\hline
\end{tabular}

a Date $1=1$ July. ${ }^{*} P<0.05$ (Mann-Whitney $U$-test), NS $=$ not significant.

the limiting sex, which seems to be the case with Semipalmated Sandpipers in at least some years (pers. obs.), males may have greater difficulty in initially establishing territories near their natal sites. As suggested by Moore and Ali (1984), it is not always necessary to use an inbreeding-avoidance hypothesis to explain patterns of sex-biased dispersal.

Although there was no significant sex bias in adult return rates, specific site tenacity was greater in adult males than in females (Tables $2,3)$. Therefore, sex biases not large enough to be evident as significant differences in return rates might be shown only by differences in site tenacity within the study area, as noted by Greenwood (1980) and Oring and Lank (1982). A number of other researchers also have reported a stronger adult male site tenacity in monogamous, male-territorial shorebirds, e.g. the Piping Plover (Charadrius melodus, Wilcox 1959), Dunlin (Soikkeli 1967), Eurasian Oystercatcher (Haematopus ostralegus, Harris 1967), Killdeer ( $\mathrm{Ch}$. vociferus, Lenington and Mace 1975), and Western Sandpiper (C. mauri, Holmes 1971).

Western Sandpipers are closely related to Semipalmated Sandpipers and are much the same size (Cartar 1984). Holmes (1971) found that returning male Western Sandpipers nested an average of $38 \mathrm{~m}(n=38)$ from their previous nest, and females $69 \mathrm{~m}(n=25)$. This is similar, although slightly lower, than the values obtained in this study for Semipalmated Sandpipers (means of $66 \mathrm{~m}$ for males and $138 \mathrm{~m}$ for females), which is probably due to the higher density and smaller territories of the Western Sandpipers. Holmes (1971) obtained an average return rate of $58 \%$ for male and $49 \%$ for female Western Sandpipers, which was similar to our results for Semipalmated Sandpipers.

Site tenacity apparently was little affected by 
whether one or two years had elapsed between nesting attempts. If the birds only consider the position of their most recent nest when selecting a new site, one might expect, on average, distances from the original nest to increase with every year elapsed. This was the case for reunited pairs and mate-change males but not for mate-change females, probably because females usually change territories when they change mates (Table 1). Nest sites did not appear limited, although some nestcups were reused as many as 4 times in $4 \mathrm{yr}$ by Semipalmated Sandpipers or by different species. This was fairly uncommon, and most pairs produced several new scrapes (some as many as 6) before a nest site was chosen (pers. obs.). Even when an old cup was reused, there usually were several new scrapes nearby, and often an old cup was scraped but not used.

Return to an area where a bird has bred successfully may not ensure success in the same area again, but in a fairly predictable environment it could increase the probability of success. A number of studies have demonstrated higher return rates for previously successful, compared to unsuccessful, nesters [e.g. Gray Catbirds (Dumetella carolinensis), Darley et al. 1977; Long-billed Curlews, Redmond and Jenni 1982; Spotted Sandpipers (Actitis macularia), Oring and Lank 1982, Oring et al. 1983]. Although return rates also were lower for unsuccessful nesters in this study (Table 4), actual site tenacity was not significantly different for previously successful vs. unsuccessful nests (Table 5). Reasons for the lack of difference in distance moved are not known. However, because predation was by far the major cause of nest failure from 1980 to 1982 (Gratto 1983: Table 2.2), moving farther away from an unsuccessful nest within the same territory might not have resulted in a decreased chance of predation. The birds might instead have chosen a new type of nest site nearby (e.g. denser willow, higher grass, centre of island). This was not tested here because nest sites were not analyzed in detail.

Wilcox (1959) found that mate change influenced adult site tenacity in the Piping Plover. In the present study the effect of mate change on site tenacity was strongest in females (Table 3). This agrees with the suggestion of Soikkeli (1967) and Holmes (1971) that most sandpipers do not mate before arriving on the breeding grounds. Males establish a territory (most often in the same area as the previous year), and females pair with their previous mate only if they return to the same territory. In this way females that change mates would be likely to change territories as well, while males would nest in the same territory. Soikkeli (1967) proposed, therefore, that site tenacity was very important in promoting mate fidelity.

Mortality also obviously has an effect on the level of mate fidelity in a population. In 1983 and 1984 , the most completely censused years, overall return rates (birds seen in the area or at a nest) from the previous year were $67 \%(93 /$ 139 ) and $49 \%$ (95/192). These represent minimum survival estimates, because birds that do not return may still be alive. The lower value probably indicates an actual decline in adult survival rates between 1983 and 1984. Snowmelt occurred a month later than average in the study area in 1983, although Semipalmated Sandpipers nested on time and in normal densities (Gratto and Cooke MS). However, many early nesters deserted partially incubated complete clutches, a phenomenon not observed in other years. Only $6 \%(2 / 36)$ of birds from deserted nests returned, compared with $30 \%(22 /$ 73) from nests destroyed by predation and $67 \%$ (54/81) from successful nests. This low survival estimate of 1984 is likely a rare event, as the 1983 season was phenologically the latest recorded during $17 \mathrm{yr}$ of research at La Pérouse Bay (Cooke pers. obs.). Therefore, we have estimated average adult survival in our population to be closer to $70 \%$, as in 1983 . With an annual adult survival rate of $70 \%$, both members of a pair would be expected to survive and reunite (assuming that all birds return and that survival of one member of the pair is not influenced by its mate) in $50 \%$ of all pairs $(0.7 \times$ $0.7=0.5$ ). This is close to the value obtained in our study (Table 6). However, not all returning pairs remated: if both members of the pair were found in the study area in the following year, about $20 \%$ did not reunite.

This $20 \%$ divorce rate is half of the $39 \%$ obtained by Holmes (1971) for Western Sandpipers in Alaska and very close to the $25 \%$ from Soikkeli (1970) for Dunlin in Finland. Hale and Ashcroft (1982) measured the divorce rate as $11 \%$ in a population of Common Redshank (Tringa totanus). The fact that most returning mates reunite suggests some advantage in retaining the same mate and/or territory.

If mate retention is advantageous, one might 
expect previous nesting success to affect remating. Mills (1973) found that Red-billed Gulls (Larus novaehollandiae) with a low breeding success changed mates more often than more successful birds. In the present study there was no tendency for pairs that returned but did not reunite to have been more unsuccessful the previous year than remating pairs (Table 7).

Newton and Marquiss (1982) found that in Eurasian Sparrowhawks (Accipiter nisus), birds nesting in the same territory with the same mate usually produced more young than birds that had changed mates and territories. Similar results have been obtained in a number of seabird species (Rowley 1983). However, in a study of Snow Geese (Anser caerulescens) Cooke et al. (1981) concluded that mate change had little or no effect on reproductive success, and the same result was found for nesting success in our study (Table 8 ). However, there may be less obvious disadvantages to mate change. For example, if pair bonds take longer to form in new pairs than in remating birds, date of hatch would be later in birds that had changed mates. This was the case in 1982 (Table 9). A later hatch often results in greater chick mortality (e.g. Soikkeli 1967, Mills 1973, Harvey et al. 1979).

In conclusion, most of the data presented here on philopatry and site tenacity in the Semipalmated Sandpiper support findings for other monogamous species. However, most previous studies have not reported both return rates and internest distances. In two instances here (sexual differences and previously successful vs. unsuccessful birds), significant differences obtained by one method were not present in the other. The former instance may reflect sex biases in dispersal of adults from year to year that are too slight to be obvious in general return rates, and the latter may reflect a major response apparently not present on a finer scale (i.e. if the birds return, previous success does not affect the distance between the original and subsequent nest sites). Because site fidelity is not necessarily a more detailed measure of philopatry, decisions regarding return/nonreturn and interyear nest movements may be quite independent, and not part of the same continuum. The same variable (e.g. previous nesting success) may affect the two measures quite differently. Therefore, results based on only one measure of site faithfulness should be interpreted with this in mind.

Very few studies of fairly short-lived birds have examined the potential advantages of mate fidelity. Here, mate retention had little, if any, effect on subsequent nesting success. Site tenacity may be most advantageous to the Semipalmated Sandpiper in terms of site familiarity, and only secondarily often results in mate fidelity. Further studies on the potential causes and advantages of mate fidelity are necessary to clarify this question.

\section{ACKNOWLEDGMENTS}

We thank those at the Queen's University Tundra Biology Station who helped with this project, especially M. J. Stalker, J. Hamann, and J. D. Reynolds. We also express appreciation to everyone who helped edit the manuscript, including $\mathrm{H}$. L. McBrien, $\mathrm{K}$. Martin, J. C. Davies, R. F. Rockwell, D. B. Lank, L. $W$. Oring, and an anonymous reviewer. We thank the Churchill Northern Studies Centre for providing logistic support. This research was supported in part by funds provided by the Arctic Institute of North America, the Eastern Bird Banding Association, the E. Alexander Bergstrom Memorial Research Fund, the Canadian Wildlife Service, the Natural Sciences and Engineering Council of Canada, and the Northern Training Grants Program of the Canadian Department of Indian and Northern Affairs.

\section{LiteratURE Cited}

ABRAHAM, K. F. 1980. Breeding site selection of Lesser Snow Geese. Unpublished Ph.D. dissertation, Kingston, Ontario, Queen's Univ.

CARTAR, R. V. 1984. A morphometric comparison of Western and Semipalmated sandpipers. Wilson Bull. 96: 277-286.

Colgan, P. W., \& J. T. SmIth. 1978. Multidimensional contingency table analysis. Pp. 145-174 in Quantitative ethology (P. W. Colgan, Ed.). New York, John Wiley \& Sons.

COOKE, F., M. A. BOUSFIEld, \& A. SADURA. 1981. Mate change and reproductive success in the Lesser Snow Goose. Condor 83: 322-327.

- C. S. Findlay, R. F. ROCKWEll, \& J. A. SMITH. In press. Life history studies of the Lesser Snow Goose (Anser caerulescens caerulescens) III. The selective value of plumage polymorphism: net fecundity. Evolution.

Coulson, J. C., \& C. S. Thomas. 1983. Mate choice in the Kittiwake Gull. Pp. 361-376 in Mate choice (P. Bateson, Ed.). Cambridge, England, Cambridge Univ. Press.

Darley, J. A., D. M. SCOTt, \& N. K. TAYlor. 1977. Effects of age, sex and breeding success on site fidelity of Gray Catbirds. Bird-Banding 48: 145151.

Dixon, W. J., \& M. B. BROWN (Eds.). 1979. BMDP-79 Biomedical computer programs P-series. Berkeley, California, Univ. California Press. 
Gauthreaux, S. A., JR. 1978. The ecological significance of behavioral dominance. Pp. 17-54 in Perspectives in ethology (P. P. Bateson and P. H. Klopfer, Eds.). New York, Plenum Publishers.

Gratto, C. L. 1983. Migratory and reproductive strategies of the Semipalmated Sandpiper. Unpublished M.S. thesis, Kingston, Ontario, Queen's Univ.

GREENWOOD, P. J. 1980. Mating systems, philopatry and dispersal in birds and mammals. Anim. Behav. 28: $1140-1162$.

- , \& P. H. HARVEY. 1982. The natal and bre $\rightarrow$ ing dispersal of birds. Ann. Rev. Ecol. Syst. 13: 1-21.

Hale, W. C., \& R. P. Ashcroft. 1982. Pair formation and pair maintenance in the Redshank Tringa totanus. Ibis 124: 471-490.

HARRIS, M. P. 1967. The biology of Oystercatchers Haematopus ostralegus on Skokholm Island, South Wales. Ibis 109: 180-193.

Harvey, P. H., P. J. Greenwood, C. M. Perrins, \& A. MARTIN. 1979. Breeding success of Great Tits in relation to age of male and female parent. Ibis 121: 186-200.

HOLMES, R. T. 1971. Density, habitat, and the mating system of the Western Sandpiper (Calidris mauri). Oecologia 7: 191-208.

$\rightarrow$ Lenington, S., \& T. MACE. 1975. Mate fidelity and nesting site tenacity in the Killdeer. Auk 92: 149151.

Mills, J. A. 1973. The influence of age and pairbond on the breeding biology of the Red-billed Gull Larus novaehollandiae scopulinus. J. Anim. Ecol. 42: $147-162$.

MOORE, J., \& R. Ali. 1984. Are dispersal and inbreeding avoidance related? Anim. Behav. 32: 94112.

Newton, I., \& M. MARQUiss. 1982. Fidelity to breed- ing area and mate in Sparrowhawks Accipiter nisus. J. Anim. Ecol. 51: 327-341.

ORING, L. W., \& D. B. LANK. 1982. Sexual selection, arrival times, philopatry and site fidelity in the polyandrous Spotted Sandpiper. Behav. Ecol. Sociobiol. 10: 185-191.

— \& — . 1984. Breeding area fidelity, natal philopatry, and the social systems of sandpipers. Pp. 125-147 in Shorebirds: breeding behavior and populations (J. Burger and B. L. Olla, Eds.). New York, Plenum Publishers.

$\longrightarrow,-$, \& S. J. MAxson. 1983. Population studies of the polyandrous Spotted Sandpiper. Auk 100: 272-285.

Prater, A. J., J. H. Marchant, \& J. Vuorinen. 1977. Guide to the identification and aging of holarctic waders, B.T.O. Guide 17. Tring, U.K., Maund \& Irvine Ltd.

REDMOND, R. L., \& D. A. JeNNI. 1982. Natal philopatry and breeding area fidelity of Long-billed Curlews (Numenius americanus) patterns and evolutionary consequences. Behav. Ecol. Sociobiol. 10: 277-279.

Rowley, I. 1983. Re-mating in birds. Pp. 331-360 in Mate choice (P. Bateson, Ed.). Cambridge, England, Cambridge Univ. Press.

SHIELDS, W. M. 1983. Optimal inbreeding and the evolution of philopatry. Pp. 132-159 in The ecology of animal movement (I. R. Swingland and P. J. Greenwood, Eds.). Oxford, Clarendon Press.

SoIKKELI, M. 1967. Breeding cycle and population dynamics in the Dunlin (Calidris alpina). Ann. Zool. Fennica 4: 158-198.

- 1970. Dispersal of Dunlin Calidris alpina in relation to sites of birth and breeding. Ornis Fennica 47: 1-9.

$\rightarrow$ Wilcox, L. 1959. A twenty year banding study of the Piping Plover. Auk 76: 129-152.

The XIX International Ornithological Congress will be held in Ottawa, Canada, from 22 to 29 June 1986. Prof. Dr. Klaus Immelmann is President. The scientific program will include plenary lectures, symposia, contributed papers (oral and posters), round-table discussions, special-interest group meetings, and workshops. Pre- and post-congress excursions and workshops are planned, as well as early morning bird walks and other activities for members and accompanying members. The deadline for registration and submission of contributed papers is January 1986. Additional information, the final circular, and registration forms are available from: Dr. Henri Ouellet, Secretary General, XIX Congressus Internationalis Ornithologicus, National Museum of Natural Sciences, Ottawa, Ontario K1A 0M8, Canada. 